\title{
A study on biology and larval behaviour of fruit piercing moth of Othreis (Eudocima) materna (L.) (Lepidoptera: Noctuidae) on pomegranate, Punica granatum
}

\section{Eknath Shendge}

Department of Zoology, Dr. Babasaheb Ambedkar Marathwada University, Aurangabad431004 (Maharashtra), India

\section{Bapurao Khaire}

Department of Zoology, Anandrao Dhonde Alias Babaji College, Kada, Dist. Beed-414202 (Maharashtra), India

\section{Ramrao Chavan*}

Department of Zoology, Dr. Babasaheb Ambedkar Marathwada University, Aurangabad431004 (Maharashtra), India

*Corresponding author. Email. chavanrj@gmail.com

\section{Article Info}

https://doi.org/10.31018/

jans.v13i1.2489

Received: January 9, 2021

Revised: February 16, 2021

Accepted: February 21, 2021

\section{How to Cite}

Shendge, E. et al. (2021). A study on biology and larval behaviour of fruit piercing moth of Othreis (Eudocima) materna (L.) (Lepidoptera: Noctuidae) on pomegranate, Punica granatum. Journal of Applied and Natural Science, 13(1): 178 - 182. https://doi.org/10.31018/jans.v13i1.2489

\begin{abstract}
Among different fruit piercing moths, the genus Othreis are the most harmful, causing widespread damage to pomegranate, citrus and mango fruits causing fruit fall in tropical and subtropical countries. The present communication deals with the study on the biology of Othreis materna (L) from egg to adult's death which was carried out at room temperature of the laboratory to investigate the delicate and vulnerable stages of its life cycle. The life cycle of the moth was completed within 45-61 days, with an average 55.03 days in case of male and within 47-63 days with an average $57.07 \pm 4.92$ in case of female. Eggs hatching started at night or early in the morning and duration of hatching was 2.72 days. The eggs measured were about 0.95 to 0.03 $\mathrm{mm}$ in diameter. The freshly emerged first instar larvae were light yellowish coloured and translucent. The first instar larvae were very active after hatching and they moved 4 to 6 feet for searching the food. The larvae were fed with the leaves of Tinospora cordifolia (Giloy or Guduchi). The total larval duration in days from first, second, third, fourth and fifth instar varied from $2.12 \pm 0.01,1.81 \pm 0.05,2.87 \pm 0.02,3.90 \pm 0.11,4.74 \pm 0.38$ in days respectively and total larval period was $15.44 \pm 0.57$. Pupae were dark brown in colour and total pupation period was of $13.81 \pm 0.12$ days and total adult duration for male and female was $23.08 \pm 0.70$ and $25.20 \pm 0.66$ days respectively. The adult of $O$. materna was bright orange in colour and of medium size. The male was small than the female. This is first study of this type from Marathwada, which will help to trace the vulnerable and delicate stage of the life cycle of this O. materna.
\end{abstract}

Keywords. Behaviour, Biology, Fruit piercing moth, Life-cycle, Othreis materna (L), Pomegranate

\section{INTRODUCTION}

The moth of Othreis spp. is a destructive pest of various fruits in tropical and subtropical countries including India, Southeast Asia, Africa, Australia and South Pacific (Waterhouse and Norris, 1987). It is polyphagous pest feeding at night by piercing the skin of the ripening fruits with their strong proboscis and sucking the juice. Internal injury consists of a bruised dry area beneath the skin resulting in the development of secondary rots at the puncture site (Atachi et al., 1989). In India four species of Othreis (Eudociam) such as O. materna, O. fullonia, $O$. homaena and $O$. cajeta are serious pest on various fruits such as pomegranate, citrus, guava, papaya, grapes, tomato and mango, etc. (Sundra Babu and David, 1973). The larvae feed on Tinospora cordifolia which belongs to family Menispermaceae. According to Ramkumar et al. (2010) the Menispermaceae creepers were supported well for the survivability of the larvae, whereas presence of sclerotized blades and erectile barbs in the proboscis suggested that the moth can capable of piercing the hard-skinned fruits. So, 
provision of physical barriers such as covering of orchards with nylon net during fruit ripening season can afford protection to some extent. Kulkarni et al. (2017) Studied host specificity and biorational management of fruit sucking moth, Eudocima (Othreis) materna L. and concluded that the biopesticides viz., B. thuringiensis, $P$. luminescens and Beauvaria bassiana can be used as a promising bioagents for the management of fruit sucking moth larvae. There are various studies on biology and morphology of Othreis spp. carried out by Leefmans (1932), Marjabandhu (1933), Hargreaves (1936), Ayyar (1943), Srivastava and Bogawat (1968), Mohite et al. (2004) and Patel and Patel (2006). Stephen and Roland (2011) studied seasonal abundance and suppression of fruit-piercing moth Eudocima phalonia (L.) in a Citrus Orchard and reported that it is difficult to control the pest with insecticide because they spend only a short time on the fruits and do not breed on the affected crops due to the alternation of host plant in nearby secondary forest areas. Mohite and Deshmukh (2014) studied population density of fruit piercing moths of genus Othreis and damage caused by it to Orange orchards of Vidarbh region of Maharashtra and found that among the collected species, O. materna was found to be denser than other two species. During the present investigations which were carried out on the life stages of fruits piercing moths $O$. materna $(\mathrm{L})$. the pest on the fruits of Pomegranate (Punica granatum) of the family Punicaceae.

\section{MATERIALS AND METHODS}

The life stages of fruit piercing moth, O. materna were studied from the egg, larvae, pupa and adult. The adults 0 . materna were collected from the orchards of pomegranate from different parts of Marathwada region of Maharashtra at night time from 7:00 pm to 10:00 pm, with the help of torches and insect collecting nets. The moths were kept in double coating air mesh fabric black polyester cloth wood cages with size $27 \times 27 \times 52 \mathrm{~cm}$. Inside the cages on the outer side, the movable glass was kept and inside the cages hanging up fresh pomegranate fruits for the observation of all activity of moths such as feeding, mating and oviposition. The eggs were laid on Tinospora cordifolia leaves by the female adult. These Eggs were measured with the help of ocular micrometre and morphological observations were done under the stereoscopic binocular microscope and measurement of larvae with the help of vernier scale. The temperature of $22^{\circ} \mathrm{C}$ to $27^{\circ} \mathrm{C}$ temperature and humidity between the $60 \%$ to $75 \%$ was maintained inside the laboratory. For larval feeding plastic trays size, $38 \times 30 \times 7 \mathrm{~cm}$ were used and lastly, the pupae were transferred in adults emerging cages size $60 \times 42 \times 48 \mathrm{~cm}$. Regarding the life span of moth's female and male, ten samples were observed in the laboratory.

\section{RESULTS AND DISCUSSION}

The present study shows that the complete life cycle of O. materna was completed in 45-61 days, with an average $55.03 \pm 4.18$ days in case of male and 47-63 days with averages $57.07 \pm 4.92$ days in the female. All the measurements and structural description are shown in Table 1.

\section{Eggs Plate I (a)}

The freshly laid eggs were translucent and circular in shape but ventral region flat and attached to the substratum. Colour creamy white but after some time became faint yellowish and before hatching turned slight brown. They measured about 0.95 to $0.03 \mathrm{~mm}$ in diameter. The duration of eggs hatching was 2.72 days. The duration for eggs hatching has been noted 3 to 4 days by Kumar and Lal, (1983) and Mohite et al. (2004).

\section{Larvae}

The larval variation in weight, size, colour and characters was as follows. There are five larval instars observed in life stages.

\section{First instar (Plate I (b))}

The freshly emerged first instar larva was light yellowish coloured and translucent. It becomes green after feeding. Head was light brown coloured and present on either side six ocelli. The body segments are distinct and on dorsal side black round spot and inside round long hairy setae appeared. Abdomen ten segmented, prolegs present on 4, 5, 6 and 10 segments. The average duration of this instar was $2.12 \pm 0.01$ days.

\section{Second instar (Plate I (c))}

The larvae were greenish black in colour, but later on, they became brownish black. Similar observations were reported by Srivastava and Bogawat (1968) in O. materna. Head was brown in colour. Body soft concave dorsally and flat ventrally. The long hairy setae disappeared in the second instar. White dots appeared on the second and third thoracic region. There are whitish dots on the subdorsal region of the thoracic segments occurring up to hump. Four blue coloured indistinct patches appear on meso and metathoracic segments. There are orange spots on the lateral side of the first three abdominal segments. The anal hump on $8^{\text {th }}$ abdominal segments was with eight whitish spots-the two large brownish spots on each half of the dorsal region of the abdominal segments. The average duration of instar larva was $1.81 \pm 0.05$ days

\section{Third instar (Plate I (d))}

The larval body was black. The large orange-coloured spots are prominently evident on the first three abdominal segments and white spot also appear sub dor- 
Shendge, E. et al. / J. Appl. \& Nat. Sci. 13(1): 178 - 182 (2021)

Table 1. Showing weight, length, width, head width and average life span of O. materna (L).

\begin{tabular}{lllllll}
\hline $\begin{array}{c}\text { Sr. } \\
\text { no. }\end{array}$ & Stages & Body Weight $(\mathbf{g})$ & $\begin{array}{l}\text { Body Length } \\
(\mathbf{m m})\end{array}$ & $\begin{array}{l}\text { Body Width } \\
(\mathbf{m m})\end{array}$ & $\begin{array}{l}\text { Head Capsule } \\
\text { Width (mm) }\end{array}$ & $\begin{array}{l}\text { Average life } \\
\text { span in (Days) } \\
\text { Mean }\end{array}$ \\
\hline 1 & 1 st Instar & $0.001 \pm 1.32$ & $4.38 \pm 0.36$ & $0.7 \pm 0.07$ & $0.43 \pm 0.09$ & $2.12 \pm 0.01$ \\
2 & 2 nd Instar & $0.002 \pm 1.61$ & $11.89 \pm 0.33$ & $1.22 \pm 0.09$ & $0.74 \pm 0.10$ & $1.81 \pm 0.05$ \\
3 & 3 rd Instar & $0.108 \pm 0.01$ & $21.22 \pm 0.81$ & $2.17 \pm 0.16$ & $1.40 \pm 0.11$ & $2.87 \pm 0.02$ \\
4 & 4 th Instar & $0.426 \pm 0.025$ & $32.48 \pm 1.69$ & $3.97 \pm 0.15$ & $2.05 \pm 0.09$ & $3.90 \pm 0.11$ \\
5 & 5 th Instar & $1.410 \pm 0.100$ & $51.81 \pm 1.14$ & $8.05 \pm 0.10$ & $3.09 \pm 0.24$ & $4.74 \pm 0.38$ \\
6 & Pupa & $1.321 \pm 0.086$ & $25.26 \pm 0.75$ & $8.94 \pm 0.26$ & $6.39 \pm 0.09$ & $13.81 \pm 0.12$ \\
7 & Adult & $0.589 \pm 0.015$ & $30.05 \pm 0.98$ & $8.30 \pm 0.15$ & $5.53 \pm 0.06$ & $23.08 \pm 0.70$ \\
\hline
\end{tabular}

sally. The prolegs were back in colour and well developed. Blue spot occurred on the dorsal region of rest of the abdominal segments, the whitish spots on the last abdominal segment. The anal plate appeared on the $10^{\text {th }}$ segment. The average duration of third instar larva was $2.87 \pm 0.02$ days. The small undeveloped similar eye spot appeared on second and third each.

\section{Fourth instar (Plate I (e))}

The body was velvety black and the head was black in colour. The thoracic segment slightly blue warts present. Thorax region orange coloured spots present laterally, beside dark blue colourd spots posterodistally. During the present study, vertical rows of white spots all over the dorsal surface of the abdominal segments were observed and similar observations were also reported by Mohite et al. (2004). The last abdominal segment possessed a single median large white spot. The average duration of this instar was $3.90 \pm 0.11$ days. The similar eye spot was well developed in the fourth instar.

\section{Fifth instar (Plate I (f))}

The body was velvety black coloured. Larvae were similar like the fourth instar. Each $4^{\text {th }}, 5^{\text {th }}$, and $10^{\text {th }}$ abdominal segments bore a pair of thick prologs and flat chroches. Blue spot and some patches were present on body, at the dorsal side two orange-coloured spots on the first abdominal segment. Abdominal segments $2^{\text {nd }}$ and $3^{\text {rd }}$ are characterized by the presence of two transverse rows of white patches and large and shiny eye spot. The average duration of this instar larva was $4.74 \pm 0.38$ days. Effects of temperature and host plant condition on insect development on Spodoptera exempta has been examined by Dianne et al (2015) and revealed that rearing temperature and host plant conditions were found to have significant effects on their larval and pupal development and pupal weight.

\section{Pupae (Plate I (g))}

The pupae were dark brown in colour. Distinct wing pads and spiracles were visible on the prothorax. The anterior end of the body blunt and posteriorly conical. The dark wing pads and spiracles black in colour. The $2^{\text {nd }}$ to $8^{\text {th }}$ abdominal segments possesses a pair of lateral spiracles. The differentiated male and female, male pupa genital pore was situated midventrally on the $9^{\text {th }}$ and $10^{\text {th }}$ abdominal segments, in case of female $8^{\text {th }}$ and $10^{\text {th }}$ segments and duration were 10 to 15 days with an average of $13.81 \pm 0.12$ days. The emergence started after sunset at 7:00 pm and continued up to the early morning. The adults emerged were very small in size. Emerged moths were active and they try to fly.

\section{Adult (Plate I (h) Male (i) Female)}

The adults of $O$. materna were bright orange in colour, medium-sized. The male was small than the female. Head brown in colour. The proboscis very long and tapers at the tip. The length of forewing was 42.78 to $51.89 \mathrm{~mm}$ and the width was 17.86 to $22.06 \mathrm{~mm}$. The Sexual dimorphism in both sexes exhibited by the unique spotted coloration of forewings. Similar results are also reported by Srivastava and Bogawat (1968) and Mohite et al. (2004) in O. materna. In female large part of each forewing covered with three brown colored patches differentiated fully from each other and also distinct from the periphery due to the presence of intermediary white strips and the male three vertical and oblique brown spots merged into the large white area. The bright hind wings were not visible. Length of the hind wings was 25.73 to $32.70 \mathrm{~mm}$, while the width is 19.16 to $25.90 \mathrm{~mm}$. The hind wings were dark yellow or orange in colour containing 8 white spots arranged in a peripheral semicircular dark band. The black spherical spot centrally located on each hind wings and in both the sexes. The hind wings did not exhibit sexual dimorphism. The moths were feeding at night only. After emerging from the pupa, females had a pre oviposition period of 3 to 6 days. The mating of the adult moths occurred at night and oviposition generally occurred in early morning. Magar et al. (2015) studied on biology and larval host plants of fruit sucking moth, Eudocima materna and reported that at average $28 \pm 2^{\circ} \mathrm{C}$ temper- 

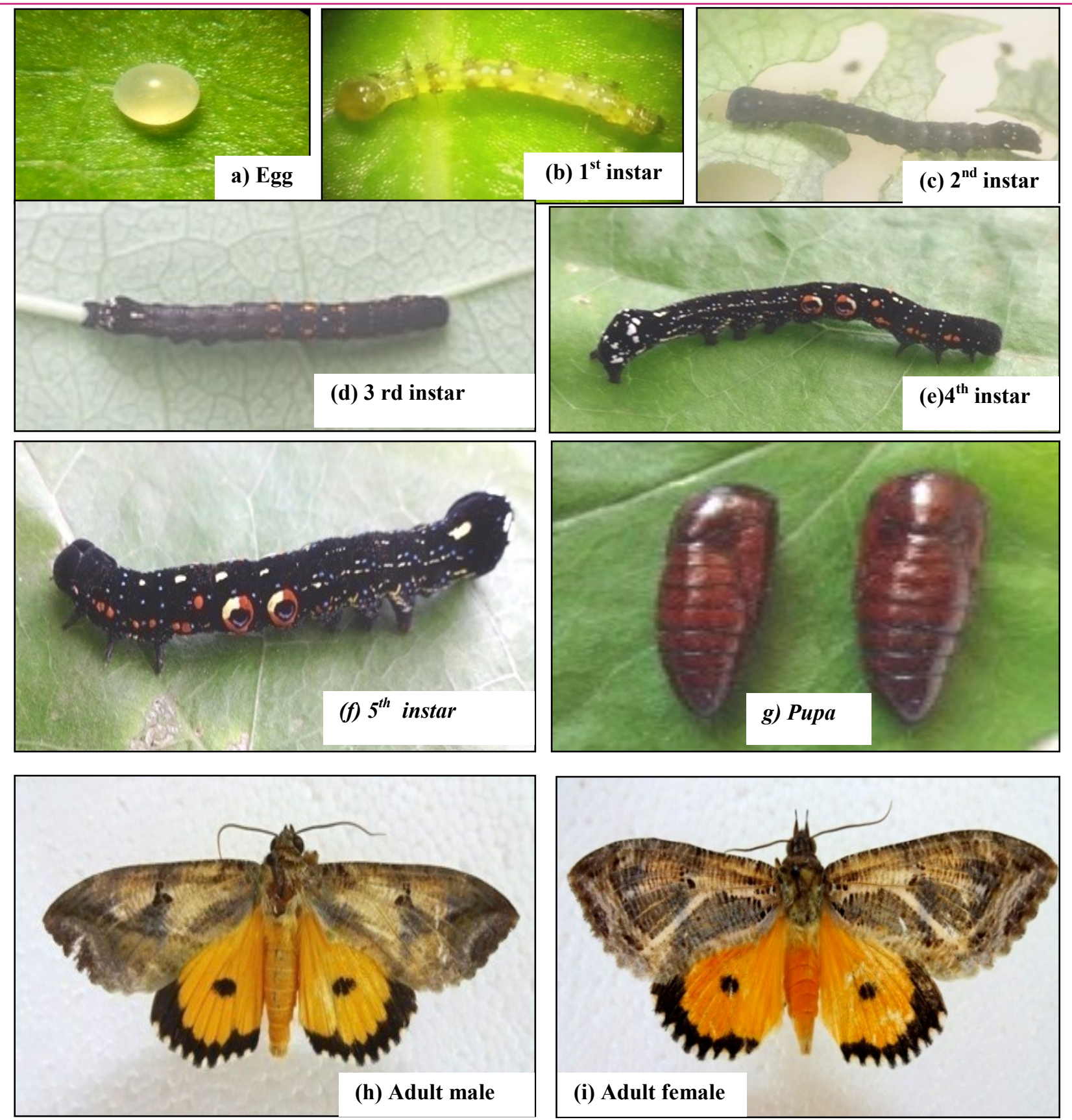

Plate I: Life cycle of Othreis materna various stages.

ature, the female moths laid eggs singly and loosely on the cloths of cages. The egg-laying capacity of female was 597 - 802 eggs per female.. The egg to adult emergence period was 31.18 days. However, the average longevity of male and female moth was 30.53 days and 31.40 days, respectively. The total life period of male varied from 52.0 days to 70.5 days with an average of 61.25 days. While in female, it ranged from 53.0 to 73.5 days with an average of 63.25 days.

\section{Behaviour of larvae from first instars to adults}

The present study observed that the first instar larvae were very active after hatching and they moved 4 to 6 feet for searching the food. Larvae generally fed at any time but fed fast in morning and night time. The first and second instars moved on the back side of the leaf of $T$. cardifoliya (Giloy) after the time of feeding at day time. Larvae colour changed from stage to stage. They stopped feeding at the time of molting. Large larvae disturb small at time of night and morning inside the trays. The fifth instar became slow and feeding was ceased and started the secretion of white silk spun in drown the leaf of cocoon made white silk spun between dried leaves of Tinospora cordifolia then underwent for pupation within 24 hours. Adult emerged moth was very small in size and after emerging they flew at free space for searching food. The feeding behaviour of larvae $O$. materna observed during the present study was vora- 
cious and similar to the feeding behaviour observed by Mallikarjun et al. (2019) who studied the role of fruit volatiles and sex pheromone components in mate recognition in fruit piercing moth Eudocima materna Linnaeus (Lepidoptera: Erebidae) and their study indicated that E.(O.) materna selective polyphagic feeding behaviour and uses olfactory cues from preferred fruits to detect and locate potential food sources. Ronald Kuen et al. (2012) studied biology and ecology of fruit piercing moth E. phalonia (L.) in citrus orchard in Sarawak, Malaysiya and concluded that moth activities were largely affected by weather, fruiting pattern and also the host alteration capabilities which supports the observations noted during our study regarding immediate search of adults for food. Ronald Kuen et al (2012) also concludes that the short stay of moths of $E$. phalonia at fruits and decision to breed on the host plant in the secondary forest made the use of insecticide ineffective this suggests that the development of IPM for fruit piercing moth in citrus is needed in view of the low success rate in controlling this pest. Therefore, understanding the biological and ecological aspects of FPM is essential in the formulation of such management practices.

\section{Conclusion}

The present investigation on morphology and behaviour of various life stages of $O$. materna, conclude that the larval stages, in general, are more delicate and vulnerable due to the effect of temperature and availability of host plant for feeding of larval stages. Therefore understanding the morphological and biological observations of FPM are essential for the formulation of management practices.

\section{Conflict of interest}

The authors declare that they have no conflict of interest.

\section{REFERENCES}

1. Atachi, P., Desmidts, M. and Durnex, C. (1989). Fruitpiercing moths (Lepidoptera: Noctuidae) as citrus pests in Benin: a description of their damage and morphology, Plant Protection Bulletin., 37(3), 111-120.

2. Ayyar, R.T.V. (1943). Notes on some fruit sucking moths of Deccan. Indian Journal of Entomology., 5, 29-33.

3. Dianne Joy D. Aguiln, Celia dr Medina and Luis Rey I Velasco (2015). Effects of larval rearing temperature and host plant condition on the development, survival and coloration of African Armyworm, Spodopteraexempta Walker (Lepidoptera: Noctuidae). Journal of Environmental Science and Management, 18 (1), 54-60

4. Hargreaves, E. (1936). Fruit-piercing Lepidoptera in Sierra Leone. Bulletin of Entomological Research. 27(4): 589605. DOI: https://doi.org/10.1017/S0007485300058685
5. Kulkarni S. R., S. K. Patil and P. N. Guru, (2017) Host specificity and bioratonal anagement of fruit sucking moth, Eudocima (Othreis) materna L., Pest Management in Horticultural Ecosystems, 23( 1), 12-16

6. Kumar, K. and Lal, S.N. (1983) Studies on the Biology, Seasonal Abundance and Host-Parasite Relationship of Fruit Sucking moth, Othreis fullonia (Clerk) in Fiji. Fiji Agric. Journal, 45(2), 71-77.

7. Leefmans, S. (1932). A Fruit -Piercing Noctuid, Othreis fullonia. Trop. Natur., XXI. (12), 224- 228.

8. Magar P.N., S.R. Kulkarni, S. K. Patil and A.S. Damre (2015) Biology and Larval host specificity of fruit sucking moth, Eudocima materna Linnaeus, Journal Ecology, Environment and Conservation Paper. 21 (3), 1351-1357

9. Mallikarjun, K. R. M., Bhanu, M. Thippaiah, Raghavendra, A., Jyotsana Sharma and A. K. Chakravarthy (2019), Role of fruit volatiles and sex pheromone components in mate recognition in fruit piercing moth Eudocima materna Linnaeus (Lepidoptera: Erebidae) Journal of Entomology and Zoology Studies, 7(3), 1381-1387

10. Marjabandhu, V. (1933). Insect pests of oranges in the northern circars. Madras Agric. J., 21:60-68.

11. Mohite, A.S., Tembhare, D.B. and Umarkar, S.P. (2004). Biology and behavior of developing stages of fruit sucking moth, Othreis materna Linn. (Lepidoptera : Noctuidae). Journal of Entomological Research, 28 (1), 37-45.

12. Mohite A. S. and C. K. Deshmukh (2014) Population density of fruit piercing moths of Genus Othreis and extent of damage in the orange orchards of Vidarbha region of Maharashtra, International Journal of Researches In Biosciences, Agriculture and Technology, (2) (II), 354-361, DOI: 10.13140/RG.2.2.12892.85128

13. Patel, M.M. and Patel, R.K. (2006). Biology of fruit sucking moth Othreis materna on sweet orange. International Journal of Agriculture Science, 2(1): 118-121.

14. Ramkumar J., M. Swamiappan, S. Raguraman and A. Sadasakthi, (2010) Larval host specificity and proboscis morphology of fruit piercing Moths, Journal of Biopesticides, 3(2), $428-431$.

15. Ronald Kuen Jui Heng, Stephen Leong Chan Teck and Franklin Ragai Kundt (2012) Biology and ecology of fruit piercing moth Eudocima phalonia (L.) in citrus orchard in Sarawak, Malaysiya, Journal of Tropical Biology and Conservation, 9(2), 176-182.

16. Srivastava, R.P. and Bogawat, J.K. (1968). Descriptions of the immature stages of a fruit-sucking moth, Othreis materna (L.) (Lepidoptera: Noctuidae), with notes on its bionomics. Bulletin of Entomological Research, 59 (2), 275-280. DOI: https://doi.org/10.1017/S000748530000 3205

17. 17. Sundara Babu, P. and David, B.V. (1973). A note on unprecedent occurrence of fruit piercing moths on grapevine. South Indian Horticulture, 21(4), 134-136.

18. 18. Stephen Chan Teck Leong and Roland Jui Heng Kueh (2011). Seasonal Abundance and Suppression of FruitPiercing Moth Eudocima phalonia (L.) in a Citrus Orchard in Sarawak, The Scientific World Journal, 11, 2330-2338. doi:10.1100/2011/753484

19. 19. Waterhouse, D.F. and Norris, K.R. (1987). Biological control: pacific prospects, 240-249, Inkata Press, Melbourne,:VIII Australia, -454. 37 (4-5). https://doi.org/10.10 02/mmnd.19900370412 